\title{
Structural Design of Variable Stiffness with Load Switch
}

\begin{tabular}{|c|c|c|c|c|c|c|}
\hline 田和 & 聡典 & (阪大 [院］) & 正 & 内藤 & 尚 & (阪大基礎工) \\
\hline 松本 & 健志 & (阪大基礎工) & 正 & 田中 & 正夫 & (阪大基礎工) \\
\hline
\end{tabular}

Toshinori TAWA, Osaka University, 1-3, Machikaneyama-cho, Toyonaka, Osaka Hisashi NAITO, Osaka University

Takeshi MATSUMOTO, Osaka University

Masao TANAKA, Osaka University

1.はじめに 主荷重方向とは異なる方向に力を加える事で 作動する荷重スイッチにより主荷重方向の剛性を切替可能 な可変剛性構造体の設計手法を提案する. いくつかの基本 構想に基づき，それを実現する構造最適化アルゴリズムを 提案する．設計例を通じてその有効性を確認する.

2.基本構想 可変剛性設計では, 荷重の増加による構造内 部境界での位相変化を利用して剛性を可変とする．㓮性が 上昇するハードニング可変剛性構造では，無負荷状態で開 口状態にある内部境界が，閾値を超える荷重が作用すると 閉口状態へと変化させる. 本研究では, 作用荷重とは別に 剛性切替のスイッチの役割を果たす荷重を印加することで, 剛性が上昇する構造を考える，すなわち，スイッチ荷重が 作用していないとき，作用荷重が印加されても内部境界は 開口状態のままであり, 剛性は変化しない, 一方, スイッ 于荷重を印加することで, 内部境界状態が変化し, 作用荷 重閾値を超えると内部境界が開口状態から閉口状態へと変 化し，剛性の上昇，すなわちハードニングを起こす。

3.ハードニング可変䦌性の位相最適化 境界 $\Gamma_{i} に$ 荷重 $t_{i}$ が

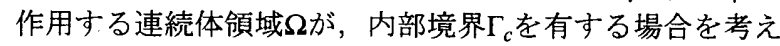
る. 作用する負荷の大きさを表すパラメータとして荷重係 数 $\alpha$ を導入し, この構造に作用する荷重 $t_{i}$ を参照荷重 $t_{i}{ }^{\circ}$ と $\alpha$ を用いて $t_{i}^{\mathrm{D}}=\alpha^{D} t_{i}^{\mathrm{D} 0}$ と表す. 添え字 $D$ は荷重の種類を区別 し, $D=w$ は主荷重, $D=s$ はスイッチ荷重を表すとする. 荷重増加にともない内部境界における開口/閉口状態が変 化する時の荷重係数を $\alpha^{D *}$ とし, 次に示す3つの内部境界の 状態を区別して取り扱い，それらの状態を表すために添え 字 $m$ を用いる.

・ $m=0$ :主荷重は作用せず，スイッチ荷重が $\alpha^{s *}$ まで作用す る $\left(\alpha^{w}=0,0 \leq \alpha^{s} \leq \alpha^{s *}\right)$.

・ $m=1$ :スイッチ荷重作用下で，主荷重が作用するが，内部 境界 $\Gamma_{c}$ 上に閉口境界 $\Gamma^{\prime} c$ は存在せず, 口開き状態で ある $\left(a^{w}<\alpha^{w *}, a^{s} \geq \alpha^{s *}\right)$.

- $m=2$ : スイッチ荷重の作用下で内部境界 $\Gamma c$ 上に閉口境界 $\Gamma^{\prime} c$ が存在し，そこで固着状態となる $\left(\alpha^{w *} \leq \alpha^{w}, \alpha^{s} \geq\right.$ $\left.\alpha^{s *}\right)$.

スイッチ荷重作用下でのみ主荷重に対してハードニング 可変剛性を示す構造設計問題を以下のように定式化する.

$$
\begin{array}{ll}
\text { minimize } & \int_{\Omega} \rho d \Omega \quad \text { with respect to } \rho \in \Omega \\
\text { subject to } & \rho_{\min } \leq \rho \leq \rho_{\max } \\
& \alpha^{D^{*}}=\min _{\Gamma_{c}^{\prime} \neq \phi} \alpha^{D} \\
& a\left(u_{k}^{(m) D}, v_{i}^{(m) D}\right)=L\left(t_{i}{ }^{D}, v_{i}^{(m) D}\right) \forall v_{i}^{(m) D} \in U_{0} \\
& L\left(t_{i}^{D}, u_{i}^{(m) D}\right)=L^{(m)^{*} D}, \\
& \alpha^{D}\left(u_{i}^{\left({ }^{(0) D}\right.}\left(x_{+}{ }^{D}\right)+u_{i}{ }^{(0) D}\left(x_{-}{ }^{D}\right)\right)=x_{-i}{ }^{D}-x_{+i}{ }^{D} \\
& x_{-i}^{D} \in \Gamma_{c-}, \quad x_{+i}^{D} \in \Gamma_{c+}, \quad \alpha^{D} \geq \alpha^{* D}
\end{array}
$$

ここで, $\rho, \rho_{\min }, \rho_{\max }$ はそれぞれ体積分率とその下限值, 上限值である. 制約条件は, 体積分率 $\rho$ に関する制約,
荷重係数 $\alpha^{D^{*}}$ に関する制約，平衡状態に関する制約，剛 性の指標である平均コンプライアンス $L^{(m) * D}$ に関する制 約, および内部境界 $\Gamma_{c}^{\prime}$ における変位に関する制約である。 この問題を有限要素で離散化し, SIMP 法 ${ }^{(2)}$ を用いて位相 設計を行う. 逐次線形計画法(SLP) と外点ペナルティ法に よる反復解法により, 体積最小化を目的として設計を行 亏.

4.設計例 設計領域は, $100 \times 100[\mathrm{~mm}]$ の正方形板とし， 対称性から設計領域を 4 等分した $50 \times 50[\mathrm{~mm}]$ の第一 象限を考える. 構造材として, 樹脂系等方性材料(ヤング 率 $E=3.1 \mathrm{GPa}$, ポアソン比 $v=0.34$, 厚さ $5 \mathrm{~mm}$ ) を想定す る. 主荷重として, この正方形板に可変剛性特性を横方 向 $(x$ 方向) 荷重を, スイッチ荷重として, 縦方向 $(y$ 方 向）荷重を考える. スイッチ荷重作用下でのみ可変剛性 を示す構造を考える. 開口状態として $y$ 軸上に軸と垂直 なスリット状内部境界を導入する. 参照荷重として, 左 右方向 $(D=w) k t^{\mu(0)}=1[\mathrm{~N}]$ の圧縮集中荷重, 上下方向 $(D=$ w) に $t^{(0)}=1[\mathrm{~N}]$ の圧縮集中荷重が作用する場合を考える. Fig.1(b) で表される設計領域を, $25 \mathrm{~mm} \times 25 \mathrm{~mm}$ の 8 節点 4 角形有限要素に離散化した. なお, 初期体積分率分布 は線分 $\mathrm{AA}^{\prime} よ り$ 原点側では $\rho=1.0$, 反対側では $\rho=0.1$ で あるとする(Fig.1). 要素密度は, [0.1, 1.0] のグレースケー ルで示す. 以上の条件で位相設計を行った結果を Fig.2に, また, 平均コンプライアンスの目標値と設計した值と体 積とそれが切り替わる荷重係数を Table.1 に示す. 平均コ ンプライアンスは, 目標值を達成しており, スイッチ荷 重が作用することでコンプライアンスすなわち剛性を可 変とできていることが分かる.
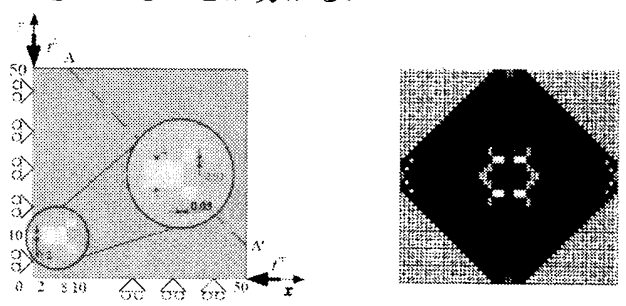

Fig.1 Quarter of design domain Fig.2 Optimal topology Table 1 Force-dependent stiffness

\begin{tabular}{lcccccc}
\hline & $\begin{array}{c}\text { Vol } \\
{[\%]}\end{array}$ & $\begin{array}{c}L^{\text {(before)W }} \\
{[\mathrm{Nmm}]}\end{array}$ & $\begin{array}{c}\mathrm{L}^{\text {(affer)W }} \\
{[\mathrm{Nmm}]}\end{array}$ & $\alpha^{* \mathrm{w}}$ & $\begin{array}{c}\mathrm{L}^{\mathrm{s}} \\
{[\mathrm{Nmm}]}\end{array}$ & $\alpha^{* \mathrm{~s}}$ \\
\hline Target & & $3.00 \times 10^{-3}$ & $1.50 \times 10^{-3}$ & & $1.50 \times 10^{-3}$ & \\
\hline Initial & 100 & $5.03 \times 10^{-4}$ & $4.36 \times 10^{-4}$ & 3258 & $5.04 \times 10^{-4}$ & 3836 \\
Optimal & 92 & $3.00 \times 10^{-3}$ & $1.49 \times 10^{-3}$ & 859 & $1.52 \times 10^{-3}$ & 2737 \\
\hline Error & & $+0.15 \%$ & $-0.71 \%$ & & $+1.2 \%$ & \\
\hline 参考文献 & & & & &
\end{tabular}

(1) 田中ら3 名, 機論, 68-673, A(2002), pp.1407-1412.

(2) Rozvany, G.I.N. et al., Structual Optimization,

Vol. 4(1992), pp. 250-252. 